\title{
PEMODELAN BASIS DATA AKADEMIK UNIVERSITAS XYZ MENGGUNAKAN PENDEKATAN OBJEK
}

\author{
Fera Tri Wulandari \\ Fakultas Ilmu Komputer, Universitas Boyolali \\ email: per.roll86@gmail.com
}

\begin{abstract}
Academic database modeling use an object approach is made by looking at the problems of the system that correspond to real-world objects. Academic database design to connect between requirements specifications and implementation that will help the development of academic information systems and determine the quality of information produced. The design of the XYZ University academic database is done using database modeling using the object approach.

The methodology carried out is directly using document collection and interviews with parties related to data processing related to academic data. After getting complete data about the object so that database design can be done. Designing is the first step after getting information to apply to the application.

The series of activities carried out in object-oriented modeling includes analysis and design of academic databases. The formed database can be used as a reference for designing academic information systems so that the information produced is accurate, fast and relevant.
\end{abstract}

Keywords: Database, object approach, academic, information systems

\section{PENDAhuluan}

Kehadiran teknologi komputer dengan kekuatan prosesnya telah memungkinkan pengembangan sistem informasi. Dengan memanfaatkan teknologi komputer, didapat manfaat berupa kemudahan menyimpan, mengorganisasi dan melakukan pengambilan terhadap berbagai data. Didukung dengan perangkat lunak dan konfigurasi perangkat keras yang tepat, suatu organisasi dapat membangun sistem informasi manajemen yang handal dan berpengaruh secara signifikan terhadap kinerja organisasi secara keseluruhan.

Kesulitan yang sering terjadi pada bagian internal perguruan tinggi adalah banyaknya pengolahan data yang memerlukan pengolahan dalam waktu yang relatif singkat. Sebagai contoh antara pengolahan data mahasiswa yang mengambil mata kuliah dan kelas yang dengan pengajar dosen. Data-data yang harus diolah antara lain data-data transaksi berupa data absensi, data mata kuliah, data transkip nilai, data jadwal ujian, data biaya pembayaran (status pembayaran mahasiswa) dan data dosen. Adanya kondisi dimana kebutuhan untuk pengolahan data yang lebih interaktif dimana pada saat ini begitu cepatnya penerapan teknologi informasi yang sangat membantu dalam penyebaran informasi secara global.

Penerapan pengolahan data ataupun aplikasi dapat diterapkan di universitas ataupun akademi. Data-data yang diolah tersebut sebelumnya merupakan data-data transaksi kegiatan mahasiswa dan universitas. Penyusunan basis data digunakan untuk mengatasi masalah-masalah pada penyusunan data, terutama mengatasi kerangkapan data. Akibat jika terjadi kerangkapan data akan menyebabkan perubahan data yang satu sedangkan yang lain tidak dirubah akan terjadi ketidakkonsistenan data.

Karena perkembanga teknologi yang sangat cepat dan kebutuhan akan informasi juga sering berubah maka dibutuhkan desain basis data yang dapat mengatasi masalah tersebut. Dengan pendekatan objek, kelas dan objek yang ditemukan dalam suatu masalah masih dapat dipakai ulang untuk masalah lainya yang melibatkan objek tersebut (reusable) dan dengan model objek, pola-pola yang cenderung tetap dan stabil dapat dipisahkan dari pola-pola yang mungkin sering berubah-ubah. Sistem yang dibangun dengan baik dan benar pada saat analisis dan perancangan akan menyebabkan berkurangnya kesalahan pada saat pengkodean. Karena pendekatan 
pengembangan lebih dekat dengan dunia nyata, sistem yang dihasilkan akan mampu memenuhi kebutuhan pemakai serta mempunyai sedikit kesalahan.

Penerapan metode analisis dan desain berorientasi objek ini telah dilakukan pada pengembangan sistem perbankan on-line [1], perancangan sistem informasi pengadaan barang, perancangan struktur basis data pada sistem informasi kredit bank xyz [2] dan perancangan pada website rencana pengembangan pendidikan dasar kota [3]. Dengan adanya pemodelan basis data akademik universitas menggunakan pendekatan objek ini dapat membantu proses perancangan sistem informasi untuk pengolahan data akademik di Universitas XYZ.

\section{KAJIAN LITERATUR}

Sistem Basis Data merupakan sekumpulan data yang saling berhubungan (integrated) yang tersimpan bersama-bersama ( shared) dengan tingkat redudansi yang terkontrol dan digunakan untuk melayani satu atau lebih aplikasi [4]. Definisi lainnya adalah sistem basis data merupakan suatu koleksi data komputer yang teri ntegrasi, diorganisasikan dan disimpan dalam suatu cara yang memudahkan pengambilan kembali integrasi logis dan catatan-catatan dalam banyak file [5].

Sebuah Sistem Manajemen Basis Data (Basis data Management Sistem / DBMS) adalah tipe partikuler dari program komputer yang digunakan oleh program aplikasi untuk mengatur dan menyediakan akses untuk data yang telah disimpan [6]. Kumpulan data yang diatur oleh DBMS yang disebut basis data. Basis data serta DBMS, bersama-sama dengan program aplikasi yang menggunakan basis data yang secara kolektif disebut sistem basis data.

Dalam meramcang basis data dapat menggunakan metode berorientasi objek. Metode analisa dan desain berorientasi objek bisa meningkatkankan efisiensi dan efektivitas yang tinggi dalam menentukan kebutuhan sistem yang akan dikembangkan. Metode analisa dan desain berorientasi objek juga merupakan metode yang komplek dan mudah diterapkan dalam rekayasa perangkat lunak. Metode tersebut juga menawarkan sebuah kerangka kerja yang baik untuk skenario [7] serta memberikan konsistensi keamanan di seluruh siklus hidup pengembangan sistem dari analisis kebutuhan sampai implementasi [1]. Fokus utama metode ini yaitu pada objek dengan melihat suatu sistem terdiri dari objek yang saling berhubungan. Objek dapat digambarkan sebagai benda, orang, tempat dan sebagainya yang mempunyai atribut dan metode. Metodologi terdiri dari pembuatan model dan domain aplikasi, kemudian menambahkan rincian implementasi pada saat pembuatan desain dari suatu sistem. Tahap-tahap metodologi berdasarkan Sistem Development Life Cycle (SDLC) digunakan dengan memperhatikan karakteristik khusus berorientasi objek yaitu analisis, desain dan implementasi [8].

Basis data berbasis objek terdiri dari Object-Oriented Data Model (OODM) , Object-Oriented Data base (OODB) dan Object-Oriented DBMS (OODBMS). OODM adalah suatu model data logika yang menangkap semantik dari objek yang didukung oleh pemrograman berbasis objek sedangkan OODB adalah sekelompok objek persistent dan sharable yang didefinisikan OODM, dan OODBMS merupakan manajer dari OODB [9]. Menurut [10], manifesto OODBMS yaitu mendukung objek objek kompleks, mendukung identitas objek, memungkinkan objek dikapsulkan, mendukung tipe atau kelas, mendukung pewarisan, menghindari tehnik binding yang dini dan dapat mengingat lokasi data.

Kelemahan OODBMS:

a. Kemungkinan korupsi basis data

b. Kekurangan dan perluasan logik

c. OODB lebih sulit dimengerti. Dibutuhkan orang yang benar-benar menguasai OODB.

Keunggulan OODBMS:

a. Fitur fitur lanjut

b. Sistem tipe yang seragam

c. Dapat menyimpan kelas dengan jumlah banyak

d. Dapat mengatasi data yang interrelated dan kompleks

\section{METODE PENELITIAN}

Tahap-tahap yang dilakukan untuk medesain database akademik diawalai dengan melakukan observasi dan wawancara, konseptualisasi, analisis, desain dan implementasi database. Permasalahan didefiniskan untuk menentukan daftar klas, 
asosiasi dan atribut yang nantinya digunakan untuk tahap desain basis data dan dilanjutkn implementasi.

\section{HASIL DAN PEMBAHASAN}

Basis data akademik didesain dengan menformat data akademik, sehingga dapat dimanipulasi untuk mendapatkan berbagai bentuk form atau laporan yang dibutuhkan oleh komponen akademik, terutama mahasiswa. Setelah observasi dan wawancara, selanjutnya dilakukan konseptualisasi dari sistem yang sedang berjalan di universitas xyz.

\section{a. Konseptualisasi}

Konseptulisasi digunakan untuk mendefinisikan tentang sistem yang akan dikembangkan, mengenai pengguna sistem, permasalah yang akan dipecahkan oleh sistem yang baru, cara kerja sistem, penggunaan sistem dan alasan dilakukanya pengembangan sistem. Konseptualisasi dari sistem informasi akademik Universitas XYZ yaitu:

Sistem Informasi Akademik merupakan sistem yang mengolah data dan melakukan proses kegiatan akademi yang melibatkan antara mahasiswa, dosen, administrasi akademik dan data atribut lainya. Sistem informasi Akademik melakukan kegiatan proses administrasi mahasiswa dalam melakukan kegiatan administrasi akademik, melakukan proses pada transaksi belajarmengajar antara dosen dan mahasiswa, melakukan proses administrasi akademi baik yang menyangkut kelengkapan dokumen dan kegiatan registrasi ataupun kegiatan operasional harian administrasi akademik. Proses pengolahan data dilakukan setiap kali terjadi transaksi akademik yang dilakukan oleh mahasiswa, sehingga pada proses ini sistem informasi akademik dapat melakukan update untuk data mahasiswa.

Dalam perancangan program administrasi akademik di Universitas XYZ ini, akan digunakan oleh bagian administrasi akademik, dimana salah satu atau beberapa dari petugas administrasi akademik akan diberikan wewenang untuk mengoperasikan program ini. Dan sistem pengolahan data ini diharapkan mampu menangani permasalahan akademik terkait dengan rencana studi dan hasil studi yang dilakukan oleh mahasiswa.
Sistem pengolahan data ini akan diaplikasikan pada bagian Administrasi khususnya pada bagian administrasi akademik di Universitas XYZ dan akan digunakan selama jam kerja yaitu jam 07.00 wib sampai dengan jam 15.00 wib. Sistem tersebut dibuat agar mempermudah proses pengolahan data akademik mahasiswa dan mempermudah kinerja bagian administrasi akademik dalam mengolah data akademik sehingga informasi dapat diakses dengan cepat. Dan petugas dapat dengan mudah melakukan pengelolaan. Sistem akan menerima melalui petugas dan sistem akan mengolah data akademik tersebut. Setiap komponen universitas dapat dengan mudah mengakses informasi tentang akademik tanpa perlu bantuan dari pihak petugas.

\section{b. Pernyataan masalah}

Permasalahn dalam sistem dinyatakan dalam suatu pernyataan masalah. Pernyataanpernyataan tersebut focus pada kegunaan sistem dan diharapkan dapat memotivasi terbentuknya sistem yang baru informasi. Masalah yang ada pada sistem informasi akademik di Universitas XYZ yaitu:

Sebuah sistem informasi akademik akan dibuat untuk menangani pengolahan data akademik Universitas XYZ. Sistem tersebut mempunyai kehandalan sebagai berikut:

1) Sistem informasi akademik dapat menangani data kemahasiswaaan, terkait dengan registrasi mahasiswa, administrasi keuangan, internal akademik, kepegawaian, penerimaan mahasiswa, permohonan surat, pengumuman dan pelaporan.

2) Proses penerimaan mahasiswa baru terdapat entry data berupa data-data pendaftar yang dilakukan petugas.

3) Mahasiswa juga harus melakukan registrasi $\underline{K R S}$ pada awal semester mengenai mata kuliah yang akan diambil sesuai dengan kurikulum yang berlaku, dengan melihat buku pedoman mengenai status matakuliah, jenis matakuliah dan kelompok matakuliah dan konsultasi kepada dosen pembimbing sebelum diserahkan kepada bagian akademik.

4) Mahasiswa memberikan form entry data

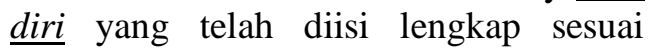
mahasiswa tersebut berasal yang selanjutnya diserahkan kepada bagian 
akademik. Data tersebut digunakan untuk update data mahasiswa serta dosen yang mengampu mahasiswa tersebut.

5) Proses update juga dilakukan terkait dengan mata kuliah, jadwal, dosen yang mengajar dan ruangan yang digunakan untuk perkuliahan. Dan mahasiswa akan mendapat jadwal sesuai kelompoknya. mahasiswa konversi mengikuti perkuliahan sesuai dengan jadwal konversi dan mahasiswa murni mengikuti jadwal murni.

6) Proses entry data mahasiswa ke sistem disesuaikan dan diklasifikasikan sesuai dengan kelompok mahasiswa, fakultas, jurusan, program studi dan jenjang yang diambil oleh mahasiswa.

7) Pada internal akademik dilakukan proses entry dan update terhadap data-data dosen, jadwal, status yang dimiliki mahasiswa dan informasi tambahan yang dibutuhkan kemahasiswaan serta surat yang terkait, seperti sk, akreditas, progdi kopertis, propinsi, daftar pt, table kurik, table konversi. Serta penyesesuaian status mahasiswa, masih sebagai mahasiswa atau alumni. Mahasiswa yang telah mengerjakan skripsi dan dianggap lulus akan statusnya akan berubah menjadi alumni.

8) Proses entry dan update juga dilakukan pada karya ilmiah. pengarang, jenis

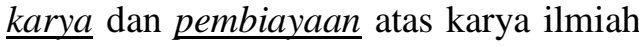
yang dihasilkan.

9) Mahasiswa dapat menampilkan informasi akademik setiap saat tanpa perlu bantuan dari pihak petugas termasuk hasil studi atau transkrip, skripsi dan jadwal perkuliahan. Bila mahasiswa yang ingin mencetak Kartu Hasil Studi (KHS) atau transkrip harus menunjukan kwitansi pembayaran matakuliah. Dan petugas akan mengecek item bayar matakuliah. Bila telah lunas, petugas akan mecetak dan mengarsip tembusan.

10) Petugas juga dapat langsung mencetak dan memberikan macam surat yang diminta oleh mahasiswa atau pengumuman yang berkaitan dengan akademik di Universitas XYZ dan mengarsip tembusan.

\section{c. Daftar Calon Klas Sementara}

Daftar calon klas sementara diambil dari kata benda dan ungkapan kata benda serta kalimat pasif yang didasarkan pada pernyataan masalah dari sistem. Daftar calon klas sementara adalah sebagai berikut:

Sistem informasi

Akademik

Kehandalan

Kemahasiswaan

Mahasiswa

Kepegawaian

Permohonan surat

Pengumuman

Pendaftar

Dilakukan petugas

Diserahkan mahasiswa

Data diri

Mata kuliah

Jadwal

Dosen

Ruangan

Perkuliahan

Kartu hasil studi

Item bayar matakuliah

Diminta oleh mahasiswa

Tembusan

KRS

Semester

Kurikulum

Status matakuliah

Jadwal konversi

Jadwal murni

Surat

Sk

Akreditas

Progdi kopertis

Propinsi

Daftar pt

Table kurik

Table konversi

Karya ilmiah

Pengarang

Jenis karya

Pembiayaan

Informasi akademik

Hasil studi

Tramskrip

Jenis matakuliah

Kelompok matakuliah

Kelompok mahasiswa

Fakultas

Jurusan

Program studi

Jenjang

Status

Skripsi

\section{d. Calon Klas}

Calon klas sementara yang telah terdaftar dieliminasi, terutama pada klas yang berlebihan dan tidak relevan atau merupakan klas samar. Selanjutnya calon klas sementara dieliminasi dan calon klas sementara yang tidak tereliminasi akan digunakan sebagai klas dalam basis data. Klas-klas tersebut antara lain:

Mahasiswa Surat

Permohonan surat Pengarang

Pengumuman Jenis karya

Pendaftar

Mata kuliah

Pembiayaan

Jadwal

Dosen

Ruangan

$\mathrm{Sk}$

Akreditas

Progdi kopertis

Propinsi

Jadwal konversi
Hasil studi

Tramskrip

KRS

Semester

Kartu hasil studi

Item bayar matakuliah

Kurikulum

Status matakuliah

Jenis matakuliah 


$\begin{array}{ll}\text { Jadwal murni } & \text { Kelompok matakuliah } \\ \text { Surat } & \text { Kelompok mahasiswa } \\ \text { Daftar pt } & \text { Fakultas } \\ \text { Table kurik } & \text { Jurusan } \\ \text { Table konversi } & \text { Program studi } \\ \text { Skripsi } & \text { Jenjang } \\ \text { Karya ilmiah } & \text { Status } \\ \text { Jadwal murni } & \end{array}$

\section{e. Calon asosiasi sementara}

Calon asosiasi sementara didata dari kata kerja dan ungkapan berpreposisi dari pernyataan masalah. Daftar calon asosiasi sementara adalah sebagai berikut:

$\begin{array}{ll}\text { Menangani } & \text { Konsultasi } \\ \text { Pengolahan } & \text { Diambil } \\ \text { Mempunyai } & \text { Disesuaikan } \\ \text { Registrasi } & \text { Diklasifikasikan } \\ \text { Entry } & \text { Dibutuhkan } \\ \text { Memberikan } & \text { Mengampu } \\ \text { Berasal } & \text { Mengerjakan } \\ \text { Diserahkan } & \text { Dilakukan } \\ \text { Update } & \text { Dihasilkan } \\ \text { Mengajar } & \text { Menampilkan } \\ \text { Digunakan } & \text { Mencetak } \\ \text { Mengikuti } & \text { Menunjukan } \\ \text { Melakukan } & \text { Mengecek } \\ \text { Diambil } & \text { Dimiliki } \\ \text { Melihat } & \text { Mengarsip }\end{array}$

\section{f. calon asosiasi}

Calon asosiasi sementara yang telah terdaftar dieliminasi, terutama pada asosiasi antar klas yang berlebihan dan tidak relevan. Selanjutnya calon asosiasi sementara dieliminasi dan calon asosiasi sementara yang tidak tereliminasi akan digunakan sebagai asosiasi dalam basis data. Asosiasi-asosiasi tersebut antara lain:

$\begin{array}{ll}\text { Menangani } & \text { Melihat } \\ \text { Mempunyai } & \text { Disesuaikan } \\ \text { Entry } & \text { Diklasifikasikan } \\ \text { Memberikan } & \text { Mengampu } \\ \text { Berasal } & \text { Menampilkan } \\ \text { Update } & \text { Mencetak } \\ \text { Mengajar } & \text { Mengecek } \\ \text { Mengikuti } & \text { Dimiliki }\end{array}$

\section{g. Daftar atribut}

Atribut yang didapat dari klas-klas yang ada antara lain sebagai berikut:

$\begin{array}{ll}\text { kode_jur } & \text { sks_pl } \\ \text { kode_ruang } & \text { Prasarat } \\ \text { Kapasitas } & \text { kode_kmtk }\end{array}$

\begin{tabular}{|c|c|}
\hline Lebar & no_pendaftaran \\
\hline Panjang & Kegiatan \\
\hline kode_kurik & kode_karya \\
\hline kode_mtk & kode_progdi 1 \\
\hline kode_sem & kode_progdi 2 \\
\hline kode_pt & pend_asal \\
\hline kode_univ & kode_jenis \\
\hline Singkatan & kode_item \\
\hline Tgl_berdiri & no_surat \\
\hline Telephone & Tanggal \\
\hline Fax & Dana \\
\hline E_mail & kode_biaya \\
\hline$\overline{\mathrm{Web}}$ & kode_jadwal \\
\hline kode_jenjang & kode_surat \\
\hline sks_lulus & Asal \\
\hline Status & Isi \\
\hline peninjauan_kurik & Senin \\
\hline Label & Selasa \\
\hline mulai_sem & Rabu \\
\hline kode_sk & Kamis \\
\hline penanda_tgn & Jumat \\
\hline kode_progdi & Sabtu \\
\hline stat_pengambilan & Minggu \\
\hline th_akad & sks_temp \\
\hline no_transkrip & $\mathrm{pt} 1^{-}$ \\
\hline Periode & pt2 \\
\hline tgl_wisuda & pt3 \\
\hline tgl_lulus & pt4 \\
\hline stat_pembayaran & pt5 \\
\hline stat_konversi & pt6 \\
\hline kode_jmtk & pt7 \\
\hline nilai_tgs & pt8 \\
\hline nilai_mid & pt9 \\
\hline nilai_uas & pt10 \\
\hline sks_tm & pt11 \\
\hline sks_pr & pt12 \\
\hline
\end{tabular}

\section{h. Model Objek}

Setelah tabel-tabel dalam database akademik telah terbentuk, maka akan terlihat relasi antar tabel yang digambarkan dalam diagram model objek pada gambar 1 .

\section{KESIMPULAN}

Desain database akademik Universitas XYZ menggunakan suatu teknik atau cara pendekatan objek dengan melihat permasalahan dari sistem. Penggunaan metode berorientasi objek memungkinkan pengembangan sistem cukup menggunakan satu metodologi saja, dari tahap analisis, perancangan, pemrograman dan pengujianya. 


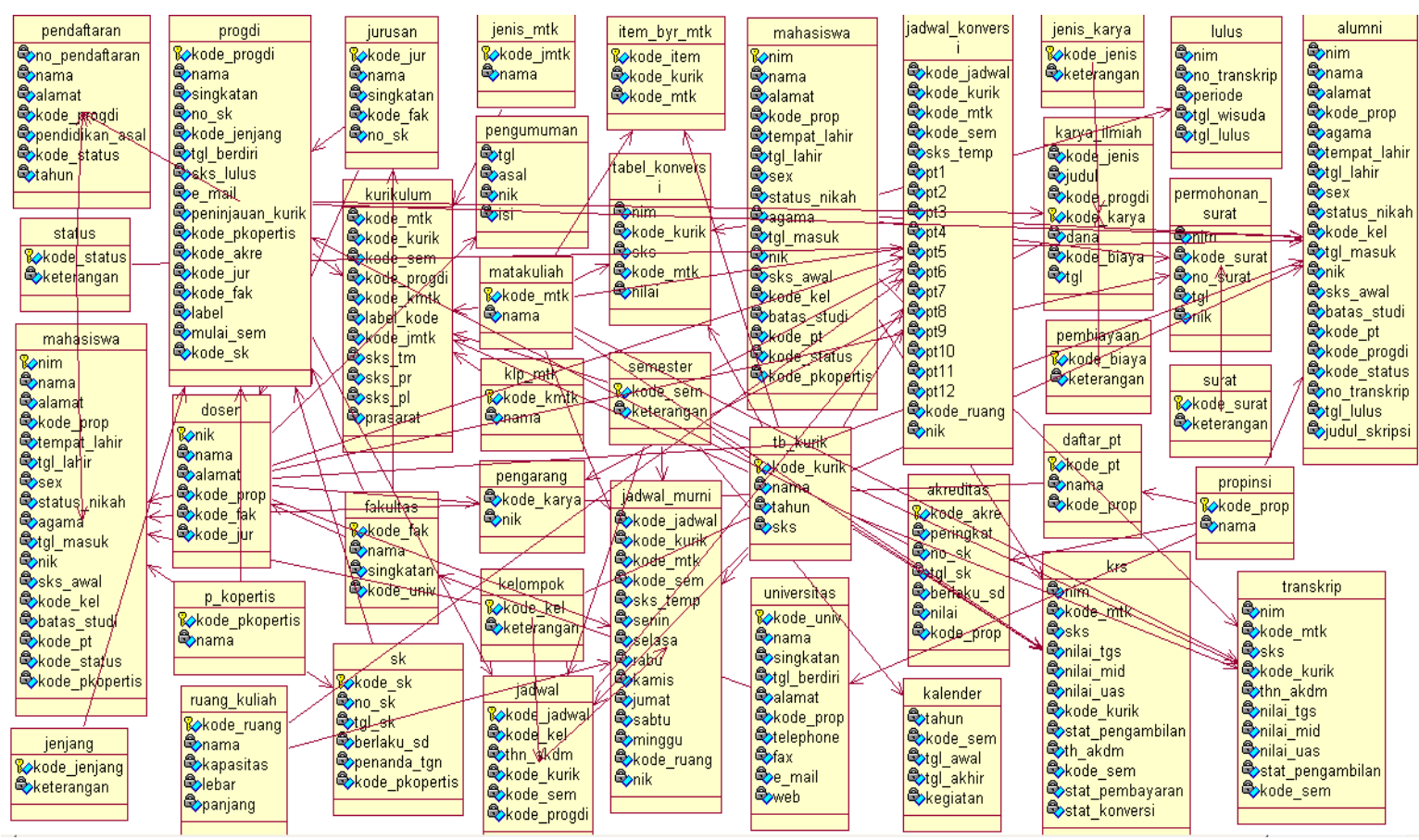

\section{Gambar 1. Model Objek}

Dengan selesainya pemodelan basis data akademik Universitas XYZ ini dihasilkan desain basis data akademik untuk menghubungkan antara spesfikasi kebutuhan dan implementasi yang akan membantu pihak pengembang sistem, karena database merupakan komponen utama bagi pengembangan sistem informasi akademik dan menentukan kualitas informasi yang dihasilkan.

\section{REFERENSI}

[1] Kyung, S. J. dan Jung, W. W., 2014,'Development of Object-Oriented Analysis and Design Methodology for Secure Web Applications". International Journal of Security and ItsApplications Vol.8(1)

[2] Candra, I., 2007, Perancangan Struktur Basis Data Berorientasi Objek pada Sistem Informasi Kredit Bank xyz,. Seminar Nasional Teknologi 2007, Yogyakarta.

[3] Gusriva, R., 2017, Analisa Dan Perancangan Berorientasi Objek pada Website Rencana Pengembangan Pendidikan Dasar Kota, Jurnal KomTekInfo, Vol. 4 (2) : 208-213
[4] Date, C.J., 2000, An Introduction to Database Sistem 7th Edition. AddisonWesley Publishing Company,Inc

[5] McLeod, R., 2001, Sistem Informasi Manajemen : jilid I, edisi ke-tujuh. Alih bahasa : Hendra Teguh, SE. AK., PT Prenhallindo, Jakarta.

[6] Mick, R., Eaglestone, B., 1998, Object Database An Introduction, Mc Graw Hill, USA

[7] Jakimi, A. dan Koutbi, M., 2009, "An ObjectOriented Approach to UML Scenarios Engineering and Code Generation". International Journal of Computer Theory and Engineering, Vol. 1(1):1793-8201.

[8] Sutopo, H. A., 2003, Analisis dan Desain Berorientasi Objek, J\&J Learning, Yogyakarta

[9] Connolly, T., Begg, C., 2005, Database Sistem: A Practical Approach to Design, implementation, and Management, fourth edition. Addison Wesley. Eng land .

[10]Hariyanto,B., 2004, Sistem Manajemen Basisdata, Informatika, Bandung. 